\title{
Security of Local Communities on an Entity Basis
}

\section{Bezpieczeństwo społeczności lokalnych w ujęciu podmiotowym}

\section{- Abstrakt •}

Wymiar bezpieczeństwa obejmuje szeroki zakres podmiotów, począwszy od jednostki ludzkiej, poprzez różnorakie zbiorowości ludzkie i organizacje, w tym państwa, narody, grupy etniczne, a skończywszy na cywilizacjach i społeczeństwie Ziemi. Zróżnicowanie podmiotów bezpieczeństwa społeczności lokalnych powoduje potrzebę ich uporządkowania, zaszeregowania do odpowiednich kategorii i przyporządkowania im właściwych warunków funkcjonowania, wartości chronionych (wartości bezpieczeństwa) i wynikających z nich możliwości, wyzwań i zagrożeń.

Słowa kluczowe: bezpieczeństwo; podmiot; społeczność lokalna; samorząd; więzi

\section{- Abstract •}

The subjective dimension of security covers a wide range of subjects, ranging from an individual, through various human communities and organizations, including states, nations, ethnic groups, and ending with civilizations and the society of the Earth. Diversification of the security entities of local communities causes the need to organize them, rank in appropriate categories and assign appropriate operating conditions, protected values (values of security) and the opportunities, challenges and threats resulting from them.

Keywords: safety; entity; local community; local government; bonds

\section{Security Entity of Local Communities}

The security of local communities is considered in many dimensions and through the prism of competences, tasks of self-government bodies responsible for security. In many publications, we encounter legal, forensic, historical, subject, subjective, spatial, temporal, cultural and ecological analyses, as well as in the context of crisis management and civil protection. 
The internal security of the state, including the problems of functioning in the local space, has a subjective dimension. From the beginning of the civilization, human behaviour directed at the elimination of threats was the basis of existence, functioning of man and community. Together with development they have undergone changes and modifications reaching a modern state. Questions were asked and answers were sought, the common denominator of which is the subject of our interactions. The analysis of security from the perspective of the subject will allow to specify the content, needs and especially preferred values subject to protection.

Bolesław Balcerowicz and Ryszard Zięba, according to the subjective parameter, list national and international security; Jerzy Stańczyk lists international, national and individual security. Interesting from the point of view of our considerations is the concept of Lech Chojnowski's security analysis levels (Chojnowski, 2011). The subjective dimension of security covers a wide range, ranging from the individual, through various human communities and organizations, including countries, nations, ethnic groups, and ending with civilizations and the society of the Earth (Table 1).

Table 1. Structure of the International Community (the Society of the Earth)

\begin{tabular}{|l|}
\hline Earth society, human species \\
\hline $\begin{array}{l}\text { Civilizations, society of states, regions (e.g., Europe, the Middle East), } \\
\text { supranational and transnational communities }\end{array}$ \\
\hline State, nation, society \\
\hline Local communities, groups and social organizations in the state \\
\hline Individual \\
\hline
\end{tabular}

Source: Chojnowski, 2011, p. 38.

The diversity of security entities causes the need to organize them, rank in appropriate categories and assign appropriate operating conditions, protected values (values of security) and the opportunities, challenges and threats resulting from them. The isolated horizontal international structures form the basis for the concept of levels of security analysis. Each of them was assigned an adequate level of analysis: the international system, the international subsystem, the level of the state and the nation (individual level), the level of local communities and numerous human and organizational groups functioning in the states (sub-individual level), and the level of the individual (Table 2). The layered arrangement of security entities allows to identify entities operating at particular levels and to analyse interactions occurring between them at the same level, as well as between entities located next to each other and at different levels (Chojnowski, 2013, pp. 190-192). 
According to Lech Chojnowski, the separation of "levels of security analysis also allows to indicate places where processes related to security occur. They are also a source of explanations for phenomena (...) and allow to build appropriate security theories. In addition, the levels of analysis make it possible to identify what is important to ensure safety on each of them - which should be subject to special protection" (Chojnowski, 2013, p. 192).

Table 2. Security Analysis Levels

\begin{tabular}{|l|l|c|}
\hline \multirow{5}{*}{$\begin{array}{l}\text { Level of international } \\
\text { relations }\end{array}$} & $\begin{array}{l}\text { International relations } \\
\text { (Earth society, international society, human species) } \\
\text { (Global security) }\end{array}$ & $\mathrm{I}$ \\
\cline { 2 - 2 } & $\begin{array}{l}\text { International subsystem } \\
\text { (civilizations, countries, nations, societies of specific regions) }\end{array}$ & $\mathrm{T}$ \\
& (Regional security) & $\mathrm{R}$ \\
\cline { 2 - 2 } & Individual & $\mathrm{R}$ \\
\hline \multirow{5}{*}{$\begin{array}{l}\text { The internal dimension } \\
\text { of state security/ }\end{array}$ /national security } & (nation, state, state society, international corporations) & $\mathrm{E}$ \\
\cline { 2 - 2 } & (state security/national security) & $\mathrm{L}$ \\
& (Hub-individual & $\mathrm{A}$ \\
& local communities, social groups and organizations (pressure \\
groups, interest groups, bureaucracies, ethnic groups, & $\mathrm{T}$ \\
& national minorities)) & $\mathrm{I}$ \\
\cline { 2 - 3 } & (Local security) & $\mathrm{O}$ \\
\cline { 2 - 3 } & Human Individual & $\mathrm{S}$ \\
\hline
\end{tabular}

Source: Chojnowski, 2011, p. 38.

An important element of the contemporary security environment is the creation of various problems that are located at different levels of the structure of society. Their subject-spatial scope may - but do not have to - coincide with the scope of the effects of these problems caused by them. They may refer to the subject and the area that created them, but may also have a broader or narrower scope, moving to other levels of the international community structure (Chojnowski, 2013, p. 192). The example of the attack on the WTC towers on September 11, 2001 confirms the thesis. Global sources can cause local effects and vice versa, local sources of threats can lead to international and global consequences. 


\section{Local Community}

In the study of the security of local communities, it is important from the point of view of further considerations to specify the concept of the local community as an entity to which safety measures are directed. It belongs to sociologically defined concepts that are not precisely defined. In scientific publications, concepts of the local community, the territorial community used interchangeably can be found. Paweł Rybicki characterized the territorial community as embracing "all social clusters based on connecting people to a specific area", "embracing the multiplicity of local clusters" (Rybicki, 1972, p. 17). In the modern sense, the territorial community is the state, province, commune, etc. According to Hanna Podedworna, the term 'local community' refers to people related to their place of residence, a specific housing estate, city, village, where there is no social cohesion between them. This is expressed in the absence of social ties, lack of disposition to take collective action and solve common problems. The inhabitation of a common geographical area does not always give the reason to a sense of social identity and is not a sufficient basis for creating social bonds (Podedworna, 1999, p. 112).

The basic requirement that distinguishes the local community from related concepts is cohesion, bond, social integration, and the pursuit of common goals. According to The Sociological Dictionary, the local community (local group) is "a community inhabiting a common territory, relatively self-sufficient, based on a solid system of social ties and interactions; it is characterized by a strong sense of belonging of individuals to the group and identification of individuals with the group" (Olechnicki \& Załęcki, 2000, p. 201). For Paweł Starosta, the local community is a socio-spatial structure that "is created by people who remain in social interactions and dependencies within a given area and has some common interest or sense of group and spatial identity as elements of common ties" and the ability "to take joint actions to solve [these people's] problems" (Starosta, 1995, pp. 30-31).

According to Jonathan H. Turner, "people live and move in a certain physical space, and if the space is organized - roads, schools, churches, local government, workplaces and other structures - they are called the local community. It is, therefore, a social structure that organizes both the place of residence of people and their physical or, in other words, geographical space" (Turner, 1998, p. 62). And what is important, he emphasizes that when talking about the local community he means the community of small villages and giant metropolises.

Mariusz Rozwadowski treats the local community as "a community inhabiting a separate, relatively small territory, such as a parish, village or housing estate in 
which there are strong ties resulting from a community of interests and needs, as well as a sense of rooting and belonging to a place inhabited" (Rozwadowski, 2014). In sociology, as elements constituting the local community, the following are mentioned:

1) space (geographically separated area) and territory (the area occupied by the human population),

2) the population inhabiting this territory,

3) social interactions between people living in the territory,

4) common ties between people and institutions, which makes the community characterized by internal integration, which in turn enables taking joint actions to solve local problems,

5) a sense of belonging to a place of residence, expressed in the attitudes referred to as so-called 'local patriotism' (Rozwadowski, 2014).

Barbara Szacka in the $10^{\text {th }}$ chapter of The Introduction to Sociology considers the important problem of transformation of traditional local communities into contemporary territorial communities and the revival of the idea of locality as a new formula of the local community in the 1980s (Szacka, 2008). In the era of the industrial revolution, migration of rural population to cities, the disappearance of traditional social ties, in the nineteenth century, the transformation of local communities in territorial communities begins. The culmination falls in the middle of the twentieth century, in Poland it is connected with the implementation of political and economic assumptions of real socialism. We observe intentional actions aimed at breaking down traditional social structures, including multigenerational families (multi-family housing, retirement homes, nurseries, kindergartens, boarding schools, etc.).

In the eighties of the twentieth century, in the world we observe a revival of the idea of locality meaning, according to Kazimierz Z. Sowa, "relative autonomy and empowerment of specific local communities in the economic, social and cultural spheres within a broad socio-spatial and political system" (Szacka, 2008, p. 233). In Poland, we observe a similar phenomenon and it is a reaction to the state's ineptitude and central authority in solving local problems. It coincides with the democratic changes of 1989.

In the ideology of contemporary locality, nostalgia for the traditional local community is combined with contemporary pragmatism, which emphasizes the benefits of the activity and involvement of local action groups and the possibilities of local communities. The importance of local activity for the development of society and the state is emphasized (Szacka, 2008, p. 235). Barbara Szacka indicates the relationship between the ideology of locality and the rebuilding of civil socie- 
ty. "The ideology of locality and local development has a clear political dimension, which in contemporary Poland, in the era of deep political transformations, is particularly visible. The transformation of territorial communities into empowered local communities is one of, perhaps even the most important one, paths leading to the rebuilding of civil society, a society in which there are many associations that are independent of the bureaucratic structures of the state, initiated by citizens to solve various social problems on their own (Szacka, 2008, p. 235).

The condition for the development of the location is democracy, decentralization of political authorities and transfer of specific powers to local governments (Starosta, 1995, p. 19). The pattern of the local community, being a community as well as the traditional community, but functioning on modern principles, is the local self-government community, for which space and territory are the natural basis for voluntary association. It is a community open to new members. Through voluntary associations and other associations, community members participate in various spheres of collective life. "Development programs are created by citizens and cooperating local associations and organizations. Local power elites are selected by democratic election procedures. Members of the community are characterized by strong identification with the place of residence and active participation in local political life" (Szacka, 2008, p. 235).

\section{Social Integration, Ties and Their Breakup}

In all definitions of local communities there is a bonding element, which is a social bond connecting the "members of a territorial collectivity". According to The Sociological Dictionary, a social bond is the totality of relations, relationships and dependencies that bind an individual to a group, collectivity, social control centres or other entity; social bond connecting individuals into groups is based primarily on the awareness of belonging to a group, community of values and interests, putting the interests of the group on its own, identifying actions and beliefs with the group's actions and beliefs, which is the result of sharing basic group conformism" (Olechnicki \& Załęcki, 2000, p. 244). Among many other definitions, the one formulated by Jan Szczepański, deserves special attention. He described the bond as: "an organized system of relations, institutions, means of social control, bringing together individuals, subgroups and other components of the community into a whole capable of duration and development" (Szczepański, 1970, p. 239).

With such a broad definition of social ties, Danuta Walczak-Duraj distinguishes three basic states or social situations signifying a bond: 
1. Ties as something natural, spontaneous, usually not subject to reflection of individuals participating in this relationship. It can be described as a natural bond (e.g., connecting mother and child).

2. A bond as an intentional relationship in which relations and relationships between partners are based on the principle of contract or willingness to join an already cohesive group. This bond can be called union or constituted arbitrarily. This bond emotionally engages its members and involves deliberate action.

3. Ties as coercion, pressure, something external to partners of interaction, something imposed. It can be called as formed from outside, or even under pressure. In this context, it is interesting to consider the view of Ferdinand Tönnies, who in the definition of social ties underlines coercion, for him the bond is the opposite of freedom, it is duty, lack of consent (Walczak-Duraj, 1998, p. 20).

In a broad sense of social ties, everything that leads to the creation and development of groups and other social groups is located. Connecting factors include all causal and goal oriented phenomena, external and internal, acting independently of consciousness and made aware by the individual (Walczak-Duraj, 1998, p. 21). Werner S. Landecker distinguishes four types of social integration that are a combination of norms, people and their behaviours:

1. Cultural integration - created on the basis of specific cultural patterns.

2. Normative integration - an indicator of the degree of conformist behaviour in the social group, compliance between group norms and behaviours.

3. Communicative (communication) integration - involving the exchange between members of a group of symbols, meanings and information.

4. Functional integration - related to the process of exchange of services between group members (Walczak-Duraj, 1998, pp. 21-22).

From the point of view of the security of local communities, social integration plays an important role, but also the processes of the breakdown of social ties and the consequences connected with them. The condition of anomie ${ }^{1}$ triggers the collapse of the current regulatory system as a result of the breakdown of existing and accepted norms, recognized values and social ties. According to A.M. Rose,

${ }^{1}$ Anomie - (according to E. Durkheim) the state of confusion arisen as a result of the weakening of the impact or disintegration of norms in which society may be found as a result of the collapse of the social order. The lack of common values causes that social control of the behaviour of individuals becomes ineffective, which leads to chaos and disorganization (Olechnicki \& Załęcki, 2000, p. 244). 
"social disorganization manifested in the form of one or many social problems occurs when a significant part of meanings and values cease to be sufficiently internalized to guide the behaviour of the majority of people still in physical contact with each other" (Rose, 1954, p. 12).

Robert K. Merton analyses anomie in the sociological approach, he makes a separation of cultural and social structures in the human environment. The cultural structure is defined by him as "a team guiding the behaviour of normative values, common to members of a particular society or group. The social structure is understood as an organized set of social dependencies in which members of a society or a group are involved in various ways" (Merton, 1982, p. 225). Therefore, it understands anomie as "a collapse occurring in the cultural structure, occurring especially when there is a strong discrepancy between cultural norms and aims and socially structured possibilities of group members' action in accordance with these norms" (Merton, 1982, p. 225). Robert K. Merton cites indicators of anomie subjectively experienced:

1) a sense of indifference of local community leaders to the needs of the individual,

2) the belief that little can be achieved in a society whose functioning is perceived as essentially impossible to predict and chaotic,

3) belief that achieving life goals is rather impossible,

4) sense of nonsense,

5) belief that when it comes to social and psychological support, man cannot count on his own friends (Merton, 1982, p. 227).

\section{Values in Subjective Analysis of Security}

The notion of values is undoubtedly one of the most frequently used, most popular and universal categories. It appears in colloquial and scientific language, according to Raymond Ruyer: "by opening a book on values, we never know in advance whether we will have to deal with:

1) a philosophical treatise;

2) with a psychological dissertation;

3) with a sociological dissertation;

4) with the economic treaty;

5) with a logical dissertation;

6) with a moral treaty;

7) with a dissertation on general philosophical issues" (Kotłowski, 1968, p. 34). 
In this situation, to adopt a definition of value is not easy and simple. Otherwise it will be formulated by an idealist, or else a materialist, and among them a sociologist, psychologist, philosopher, economist, teacher and historian. At the same time, what is important, the diversification of the notions of the concept of values and contexts in which it is used, is not only about the differences between individual scientific disciplines, but includes discrepancies created within almost every one of these sciences and among its leading representatives.

Maria Misztal distinguishes three categories of value definitions. The first of these includes values as psychological phenomena, the second - definitions that describe them as sociological phenomena, and the third - treats values as cultural phenomena (Misztal, 1980, pp. 13-14).

The sociological approach is generally taken to test values in security sciences. In the social sciences, the declared values, professed values and realized values are widely distinguished. As regulators of human behaviour, values can be treated as individual and social goals. They can be a key component ensuring social order (Wróblewski, 2017, p. 100). In approaching values, Ryszard Wróblewski takes an objective view stating that value is a characteristic of an object and has a unitary, social and state dimension. "Value - a product of feelings, convictions or beliefs of a human or state society and state power about what in the natural, social and cultural reality is positively evaluated and considered worthy of desire and aspirations" (Wróblewski, 2017, p. 102).

Among the individual values, human and citizen rights and quality of life are on the front, influenced by: living standards, costs of living, health and longevity, relations, social ties and social pathologies. Among the protected values of society Ryszard Wróblewski mentions: the supremacy of the nation, the division of power, political pluralism, the legal state, democracy, and justice. The values protected by the institution of the state include: national security, state sovereignty, territorial integrity, national identity, quality of life of citizens, social order, and public order (Wróblewski, 2017, pp. 99-127).

Concluding the reflections on values in security research, one can cite an interesting statement of the already quoted Ryszard Wróblewski: "if the safety of the reference subject is the key among other attributes, because it concerns its duration and development (understood as values), then the safety science, as a scientific discipline, is the science about values" (Wróblewski, 2017, p. 99). 


\section{Security of Local Communities}

The basis for the functioning of local communities is safe development, undisturbed implementation of the intended tasks. It expresses itself in a state of peace, certainty, lack of threat and fear in relation to basic needs and recognized values. The lack or limitation of threats is the goal of community members, but also state and local government institutions acting for and in the local environment.

Recalling the claims of Kazimierz Z. Sowa, as well as Barbara Szacka, referring to the contemporary understanding of local communities, civic society, we will refer to local self-government communities operating at the voivodship, poviat and commune level, and within the commune to the city, district, housing estate, villages and the smallest administrative unit in Poland (office of village leader). In addition to the current, traditional consideration of local communities, it can be assumed that it is a formal social organization working for the benefit of the people, but also on behalf of and for the state and the nation, a self-government community as an organization created by legislative and executive power.

Lech Chojnowski made an interesting attempt to distinguish the values of security that are important for local government communities, among which he lists:

1) survival of the local government community,

2) territorial integrity of the local government community,

3) self-government of local communities,

4) socio-economic development of self-government communities,

5) the quality of life of members of self-government communities (Chojnowski, 2013, pp. 199-203).

The survival of the self-government community as a protected value can be considered in the biological sense - the survival of community members, and the administrative sense - understood as the functioning of a specific territorial unit implementing the ideas of self-government. The integrity and territorial boundaries of local government communities are determined by regulation of the Council of Ministers and may be changed upon their request. Attempts to change the boundaries of local government entities usually meet the disapproval of residents and often with loud media protests. Most often in the background are economic issues that cause the desire to join resource-rich regions and get rid of areas that generate high costs. The arguments quoted for border correction concern the settlement and spatial system, social, economic and cultural ties.

For local self-government communities, the fundamental value is self-management understood as "a form of meeting the collective needs of specific communi- 
ties by itself or its representatives. In the formal and legal sense, it means that the state entrusts the execution of certain public tasks to associations of persons affected by the implementation of these tasks" (Antoszewski \& Herbut, 2002, p. 397).

Socio-economic development of self-government communities is treated as a protected value of security, it expresses the level of progress of life in the social and economic layer. Its condition determines the scope of the implementation of interests and the level of satisfying the collective needs and individual members of the community. The opposite of development is regress understood as "the process of reducing the degree of organization of a system or object, causing a recession, a transition of a given system (object) to the phase at least a lower (earlier) level" (Olechnicki \& Załęcki, 2000, p. 175).

Increasing the quality of life is one of the most important individual and group interests of members of local communities. They concern both higher needs as well as existential requirements covering housing, food, security, health, education and culture needs. The degree of satisfaction of all material and non-material needs determines the quality of life and it reflects the level of meeting certain standards or the implementation of certain values. In the local environment, social projects, civic initiatives, and local opportunities based on the involvement of community members are implemented. It is their commitment and success that determines the quality of life and the security of self-government communities. It is important that they are carried out in conditions without threat and the community is prepared and equipped to possibly repel them.

\section{References:}

Antoszewski, A., \& Herbut, R. (eds.). (2002). Leksykon politologii. Wrocław: Atla 2.

Chojnowski, L. (2011). Poziomy analizy bezpieczeństwa. In: S. Jaczyński, M. Kubiak, \& M. Minkina (eds.). Wspótczesne bezpieczeństwo. Perspektywa teoretyczno-metodologiczna (pp. 35-50). Siedlce-Warszawa: Wydawnictwo UPH.

Chojnowski, L. (2013). Teoretyczne aspekty bezpieczeństwa społeczności lokalnych. In:

A. Urbanek (ed.). Wybrane problemy bezpieczeństwa. Aspekty spoteczno-ideologiczne (pp. 189-208). Słupsk: Expol.

Kotłowski, K. (1968). Filozofia wartości a zadania pedagogiki. Wrocław-Warszawa-Kraków: Zakład Narodowy im. Ossolińskich.

Merton, R.K. (1982). Teoria socjologiczna i struktura spoteczna. Warszawa: PWN.

Misztal, M. (1980). Problematyka wartości w socjologii. Warszawa: PWN.

Olechnicki, K., \& Załęcki, P. (2000). Stownik socjologiczny. Toruń: Wydawnictwo Graffiti BC.

Podedworna, H. (1999). Analiza struktur społecznych. Wybrane przykłady. In: J. Pola- 
kowska-Kujawa (ed.). Socjologia ogólna. Wybrane problemy (pp. 105-119). Warszawa: Wydawnictwo SGH.

Rose, A.M. (1954). Theory and Method in the Social Sciences. Minneapolis: University of Minnesota Press.

Rozwadowski, M. (2014). Bezpieczeństwo społeczności lokalnych oraz działania zmierzające do jego poprawy. Kultura Bezpieczeństwa. Nauka - Praktyka - Refleksje, 15, 243-252

Rybicki, P. (1972). Spoteczeństwo miejskie. Warszawa: PWN.

Starosta, P. (1995). Poza metropolia. Wiejskie i matomiasteczkowe zbiorowości lokalne a wzory porządku makrospotecznego. Łódź: Wydawnictwo UŁ.

Szacka, B. (2008). Wprowadzenie do socjologii. Warszawa: Oficyna Naukowa.

Szczepański, J. (1970). Elementarne pojęcia socjologii. Warszawa: PWN.

Turner, J.H. (1998). Socjologia. Koncepcje i ich zastosowanie. Poznań: Wydawnictwo Zysk i S-ka.

Walczak-Duraj, D. (1998). Podstawy socjologii. Łódź: Wydawnictwo Omega-Praksis.

Wróblewski, R. (2017). Wprowadzenie do nauk o bezpieczeństwie. Siedlce: Wydawnictwo UPH. 